\title{
Ethylene and Postharvest Commodities
}

\author{
Elizabeth A. Baldwin \\ U.S. Department of Agriculture, Agricultural Research Service, Citrus and Subtropical Products Laboratory, \\ 600 Avenue South, N.W., Winter Haven, FL 33881
}

Ethylene is a gaseous plant hormone, the simplest olefin $\left(\mathrm{C}_{2} \mathrm{H}_{4}\right)$ and is biologically active at low concentrations (part per billion to part per million range) (Abeles, 1992; Saltveit, 1999). Since it is a gas, it is easily transported long distances via diffusion from sites of synthesis. Sources of ethylene gas include ripening fruit, senescent fruit and vegetables, wounded or stressed plant tissue (Hyodo, 1991; Morgan and Drew, 1997), combustion engines (Saltveit, 1999), bacteria from soil and water (Primrose, 1976), and a common pathogen of fruit called green mold (Penicillium digitatum) (Fukuda and Ogawa, 1991). However, ethylene gas is synthesized at some level in all plant tissues. This could be a problem in an enclosed environment, since these low levels could build up to concentrations that have an undesirable physiological/biological impact on plants. In etiolated pea seedlings ethylene causes horizontal growth, inhibition of elongation, and swelling or the triple response. In other plant parts, including stems, leaves, fruit and vegetables, ethylene causes ripening (McGlasson, 1985), senescence (Watada, 1986), inhibition of longitudinal growth, and abscission (Abeles et al., 1992; Reid, 1985).

\section{Ethylene Biosynthesis}

Synthesis of ethylene in plant tissues is from the amino acid methionine via S-adenosylmethionine (ACC) by action of enzymes ACC-synthase (ACS) and ACC-oxidase (ACO) (Adams and Yang, 1979; Imaseki, 1991; Yang and Hoffman, 1984). Ethylene can affect its own synthesis by turning on or off genes that encode some portion of its biosynthetic pathway. It is considered auto-catalytic when ethylene stimulates its own synthesis, and auto-inhibitory when it turns off continued synthesis (Mattoo and White, 1991). It is often auto-inhibitory in vegetative and immature reproductive tissues and autocatalytic in mature reproductive tissues like flowers and fruit (Lelievere et al., 1997; Saltveit, 1999). A diverse multigene family encodes ACS (Zarembinski and Theologis, 1994), which is the rate-limiting step in the ethylene biosynthetic pathway. Synthesis of ethylene requires oxygen for oxidation of ACC to ethylene by ACO, and is stimulated by low levels and inhibited by high levels of carbon dioxide (especially if the response is auto-catalytic) (Abeles et al., 1992; Sisler and Wood, 1988). Wound- or stress-response ethylene is thought to enhance activity of ACS (Applebaum and Yang, 1981; Boller and Kende, 1980). Ripening, however, after onset of the climacteric, seems to stimulate ACO (Lelievre et al., 1997).

\section{Mechanism of Action}

To have a biological effect, ethylene must bind to a receptor that is thought to reside in a membrane. If the receptor is blocked, then ethylene will have no effect (inhibition of ethylene action). Silver ions, carbon dioxide, 2,5-norbornadiene, and 1-methylcyclopropene (1-MCP) can block the ethylene receptor, and therefore inhibit ethyleneinduced effects, including its own synthesis as in the case of auto-catalytic ethylene production (Abeles et al., 1992; Saltveit, 1999; Sisler et al., 1986). An ethylene receptor has also been knocked out by antisense molecular techniques in tomato, a fruit that normally needs ethylene to accelerate ripening. These mutant tomatoes ripen very slowly (Klee and Clark, 2002).

Received for publication 2 June 2003. Accepted for publication 1 Feb. 2004.
Physiologically active levels of ethylene range from $0.005 \mu \mathrm{L} \cdot \mathrm{L}^{-1}(5$ $\mathrm{ppb}$ ) for nonclimacteric produce, and 0.1 to $1.0 \mu \mathrm{L} \cdot \mathrm{L}^{-1}$ for acceleration of ripening of climacteric fruit. Levels of ethylene produced by fruit can vary according to type of fruit and developmental stage. Internal levels of ethylene in ripe nonclimacteric fruit can range from 0.1 to $2.0 \mu \mathrm{L} \cdot \mathrm{L}^{-1}$ (lemon, lime, orange, pineapple), and 0.04 to $2500 \mu \mathrm{L} \cdot \mathrm{L}^{-1}$ in ripe climacteric fruit (apple, pear, peach, nectarine, avocado, banana, mango, passion fruit, plum, tomato) (Wills et al., 1981).

\section{Physiological Effects}

On a cellular level, ethylene can stimulate phenylpropanoid metabolism, inhibit transport of the plant hormone auxin, inhibit shoot elongation (vertical growth) (Pratt and Goeschl, 1969; Raskin, 1991), change the cell wall microfibril orientation (Takeda and Shibota, 1981), and promote synthesis of cell wall digesting enzymes (Kader, 1985; Watada, 1986). In some cases, ethylene also stimulates synthesis of anthocyanins and carotenoids (Rugini et al., 1982; Stewart and Wheaton, 1972), which are plant pigments that give blue, purple, red, orange, and yellow colors to fruit and vegetables and some of which are powerful antioxidants (Watada, 1986). At the same time, ethylene can stimulate the destruction of chlorophyll, the green pigment in plants (Kader, 1985; Saltveit, 1999; Watada, 1986). However, transgenic tomatoes with reduced ethylene synthesis did not have reduced chlorophyll loss, but did have delayed

Table 1. Advantages, disadvantages and disorders due to ethylene. ${ }^{2}$

Effects of ethylene

Useful effects

Induction and synchronization of ripening, softening, and aroma development in fruit Color development of fruit

Degreening of citrus

Flowering in pineapple

Increased sugar development (grapes)

Dehiscence in nuts

Altered sex expression in cucurbits

Harvesting aid through promotion of abscission

Reduction of chilling injury in honeydew melon

Reduced black spot in potatoes

Decreased susceptibility to infection by certain pathogens

Negative effects

Senescence of flowers

Shortened shelf-life of fruit and vegetables

Synthesis of bitter compounds in carrots

Yellowing of some vegetables like cucumber, broccoli and cabbage

Sprouting of potato

Softening of apple

Hardcore in sweet potato

Undesirable abscission of flowers, fruit, calyces and leaves

Toughening of asparagus

Increased respiration of potato tubers

Increased susceptibility to infection by certain pathogens

Stimulates phenylpropanoid metabolism (discoloration and browning)

Disorders due to ethylene

Core-browning in apples

Internal breakdown of kiwi fruit

Russet spotting of lettuce (stimulation of

Abscission of cabbage leaves

Increased sensitivity to chilling injury (avocado and grapefruit)

Internal breakdown of watermelon

In-rolling of flower petals

Closure of open flowers (Asleepy@ flowers)

Inhibition of shoot and root elongation of some bulb species

Bud necrosis in tulips

Increased respiration of iris and tulip bulbs

Epinastic curvature (downward curvature) of leaves in some ornamental plants

${ }^{2}$ Saltveit, 1999; Watada, 1986; Kader, 1985 
Table 2. Effect of 1-MCP-treated intact apples on quality of fresh-cut slices during storage for up to 14 brominated charcoal, ozone, and ultraviolet light d at $8{ }^{\circ} \mathrm{C} .{ }^{2}$

\begin{tabular}{|c|c|c|c|c|c|c|}
\hline \multirow[b]{2}{*}{ Parameter } & \multicolumn{2}{|c|}{ Day 0} & \multicolumn{2}{|c|}{ Day 7} & \multicolumn{2}{|c|}{ Day 14} \\
\hline & Control & $1-\mathrm{MCP}^{\mathrm{y}}$ & Control & 1-MCP & Control & 1-MCP \\
\hline Visual quality (1-9 scale $\left.{ }^{x}\right)$ & $9.0 \mathrm{a}^{\mathrm{w}}$ & $9.0 \mathrm{a}$ & $8.3 \mathrm{a}$ & $8.3 \mathrm{a}$ & $4.3 \mathrm{~b}$ & $1.0 \mathrm{c}$ \\
\hline Color L* & $80.1 \mathrm{a}$ & $80.1 \mathrm{a}$ & $73.4 \mathrm{c}$ & $79.3 \mathrm{~b}$ & $75.1 \mathrm{c}$ & $66.0 \mathrm{~d}$ \\
\hline Color $\mathrm{a}^{*}$ & $-6.6 \mathrm{~d}$ & $-6.5 \mathrm{~d}$ & $-5.6 \mathrm{c}$ & $-5.6 \mathrm{c}$ & $-2.6 b$ & $-1.3 \mathrm{a}$ \\
\hline Firmness $\left(\mathrm{kg} \cdot \mathrm{cm}^{-2}\right)$ & $4.7 \mathrm{a}$ & $4.9 \mathrm{a}$ & $4.4 \mathrm{ab}$ & $5.1 \mathrm{a}$ & $3.9 \mathrm{~b}$ & $4.6 \mathrm{ab}$ \\
\hline Ethylene $\left(\mu \mathrm{L} \cdot \mathrm{kg}^{-1} \cdot \mathrm{h}^{-1}\right)$ & $0.4 \mathrm{~d}$ & $\mathrm{ND}^{\mathrm{v}}$ & $1.6 \mathrm{c}$ & ND & $3.3 \mathrm{~b}$ & $5.1 \mathrm{a}$ \\
\hline Respiration $\left(\mathrm{CO}_{2} / \mu \mathrm{L} / \mathrm{kg} / \mathrm{h}\right)$ & $9.6 \mathrm{a}$ & $7.5 \mathrm{c}$ & $9.4 \mathrm{a}$ & $7.3 \mathrm{c}$ & $9.5 \mathrm{a}$ & $8.3 \mathrm{~b}$ \\
\hline
\end{tabular}

${ }^{\mathrm{z}}$ Bai and Baldwin, unpublished.

y 1 -MCP treatment was $1 \mu \mathrm{L} \cdot \mathrm{L}^{-1}$ per $18 \mathrm{~h}$ at $20^{\circ} \mathrm{C}$.

${ }^{x}$ Visual scale: the higher the value, the more acceptable the visual quality, i.e., less browning and microbial colonies.

${ }^{w}$ Means $(\mathrm{n}=3)$ in the same row that are followed by the same letter are not significantly different $(P<$ $0.05)$.

${ }^{\mathrm{N} D}=$ not detected.

lycopene synthesis, while carotenoid accumulation in transgenic melon flesh was normal (Lelievre et al., 1997), so the story is not quite clear. These cellular changes in response to ethylene are often accomplished by ethylene-induced activity of enzymes such as polygalaturonase (DellaPenna et al., 1986), chlorophyllase (Barmore, 1975), cellulase, polyphenol oxidase, peroxidase, and phenylalanine amonia lyase (Kader, 1985; Watada, 1986).

On a whole-plant level, ethylene stimulates ripening of climacteric fruit, accelerates senescence of some fruit and flowers, stimulates seed germination, adventitious root formation (Robbins et al., 1985), abscission of plant parts, respiration (See and Foy, 1983), and flower development in bromeliads (pineapple) (Saltveit, 1999). The ethylene analog, ethephon, which breaks down into ethylene (Abeles et al., 1992), has been used commercially to hasten ripening of early season apples, induce abscission of cherries and citrus, hasten ripening of late harvest blueberries, and ripening of figs (Watada, 1986) (Table 1). Ethylene is also used to ripen fruit like bananas, mangoes, melons, and tomatoes (100 to $1000 \mu \mathrm{L} \cdot \mathrm{L}^{-1}$ ) and to degreen citrus (for chlorophyll breakdown and stimulation of cartenoid synthesis, need only 1 to $5 \mu \mathrm{L} \cdot \mathrm{L}^{-1}$ ) (Watada, 1986). Generally ethylene is associated with ripening-related color and flavor development as well as softening in many fruit and vegetables (Kader, 1985; Watada, 1986).

Some undesirable effects of ethylene (Table 1) are the senescence or degradation of flowers and reduced shelf life of fruit and vegetables. For example, ethylene is responsible for yellowing of broccoli, as well as leaf abscission of cabbage, discoloration or browning of lettuce, sprouting of potato, toughening of asparagus stems, and unwanted abscission of flowers and fruit (Kader, 1995, Kays, 1991; Watada, 1996). The action of ethylene results in some commercially important disorders in fruit and vegetables including core-browning of apples, internal breakdown of kiwi and watermelons (due to synthesis of cell wall-degrading enzymes), russet spotting of lettuce (due to synthesis of secondary metabolites including phenolic compounds) (Ke and Saltveit, 1989), bitterness in carrots (again, secondary metabolites such as isocoumarin) (Soundheimer, 1957), abscission of cabbage leaves (induced synthesis of cell wall degrading enzymes in the abscission zone), and increased sensitivity to chilling injury in avocado and grapefruit (cause unknown, but perhaps membrane-related) (Kader, 1985; Kays, 1991; Saltveit, 1999; Watada, 1986).

Ethylene also plays a role in plant defense responses. It increases susceptibility of citrus to quiescent infections such as stem-end rots, but decreases decay due to wound pathogens (McCollum, 2002; Watada, 1986). Treatment of 'Golden Delicious' apples with ethylene action inhibitor, 1-MCP, resulted in reduced decay in the intact fruit during storage (Saftner et al., 2003). However, use of 1-MCP, on intact 'Gala' apples resulted in reduced ethylene synthesis (at least initially), respiration, and increased decay of the subsequent cut slices compared to fruit not treated with 1-MCP, which lowered the acceptability rating for the cut slices (Table 2). This would indicate that ethylene may play a role in the defense response of wounded apples.

\section{Amelioration of Ethylene Action}

There are ways to control ethylene levels in the atmosphere. Ethylene can be removed from the atmosphere by potassium permanganate,

(Abeles et al., 1992). Ripening and wounded fruit could be removed from storage environments, as could combustion or gas-powered engines. Soil and water would also need to be kept free of microorganisms. There are ethylene synthesis inhibitors such as aminovinylglycine (AVG) or cobalt, which inhibit ACS (Yang, 1985), but these cannot be applied postharvest. Ethylene biosynthesis can be inhibited under conditions of low oxygen and high carbon dioxide, otherwise known as a controlled atmosphere (CA), modified atmosphere packaging (MAP), edible coatings (Baldwin, 1994) and low temperature.

Genetic engineering can also be used to reduce fruit ethylene production (Saltveit, 1999). For example, in tomato key enzymes in the ethylene synthesis pathway have been down-regulated, including ACS (Oeller et al., 1991), ACO (Hamilton et al., 1990) and an ethylene receptor, and ACC deaminase has been ectopically expressed (Klee et al., 1991). Tomatoes from plants with downregulated ACS or ACO do not produce much ethylene and do not ripen. Tomatoes with inserted ACC deaminase do not make much ethylene due to the fact that this enzyme degrades ACC to $\alpha$-ketobutyric acid, a precursor of branched chain amino acids.

Once formed, ethylene can be degraded into water, carbon dioxide, carbon monoxide, and formaldehyde. When combined with atomic oxygen, carbon monoxide, ethane, propylene, acetaldehyde, propanal, butanal, hydrogen, ethylene oxide, and dioxyketene and hydroxy radicals can be formed (Abeles et al., 1992). Thus, ethylene gas has differential effects on quality attributes of fruit and vegetables and can affect growth patterns of other plants. In enclosed spaces, ethylene evolved from plants would build up to biologically active levels that could produce physiological effects.

\section{Literature Cited}

Abeles, F.B., P.W. Morgan, and M.E. Saltveit. 1992. Ethylene in plant biology, 2nd ed. Academic Press, Inc., San Diego, Calif.

Adams, D.O. and S.F. Yang. 1979. Ethylene biosynthesis: Identification of 1aminocyclopropane-1-carboxylic acid as an intermediate in the conversion of methionine to ethylene. Proc. Natl. Acad. Sci. 76:170-174.

Apelbaum, A. and S.F. Yang. 1981. Biosynthesis of stress ethylene induced by waterdeficit. Plant Physiol. 68:594-596.

Baldwin, E.A. 1994. Edible coatings for fresh fruit and vegetables: Past, present, and future, p. 25-64. In: J.M. Krochta, E.A. Baldwin, and M. Nisperos-Carriedo (eds.). Edible coatings and films to improve food quality. Technomic Publ. Co., Lancaster, Pa.

Baremore, C.R. 1975. Effect of ethylene on chlorophyllase activity and chlorophyll content in calmondin rind tissue. HortScience 10:595-596.

Boller, T. and H. Kende. 1980. Regulation of wound ethylene synthesis in plants. Nature 286:259-260.

DellaPenna, , D., D.C. Alexander, and A.B. Bennett. 1986. Molecular cloning of tomato fruit polygalacturonase: Analysis of polygalacturonase levels during ripening. Proc. Nat. Acad. Sci. 89:9789-9793.

Fukuda, H. and T. Ogawa. 1991. Microbial ethylene production, p. 279-292. In: A.K. Mattoo and J.C. Suttle (eds.). Theplant hormone ethylene. CRC Press, Boca Raton, Fla.

Hamilton, A.J., G.W. Lycett, and D. Grierson. 1990. Antisense gene that inhibits synthesis of the hormone ethylene in transgenic plants. Nature 346:284-287.

Hyodo, H. 1991. Stress/wound ethylene, p. 43-63. In: A.K. Matto and J.C. Suttle (eds.). The plant hormone ethylene. CRC Press, Boca Raton, Fla.

Imaseki, H. 1991. The biochemistry of ethylene biosynthesis, p. 1-20. In: A.K. Matto and J.C. Suttle (eds.). The plant hormone ethylene. CRC Press, Boca Raton, Fla.

Kader, A.A. 1985. Ethylene-induced senescence and physiological disorders in harvested horticultural crops. HortScience 20:54-56.

Kays, S.J. 1991. Postharvest physiology and handling of perishable plant products. Van Nostrand Reinhold, New York.

Ke, D. and M.E. Saltveit. 1989. Regulation of russet spotting, phenolic metabolism, and IAA oxidase by low oxygen in iceberg lettuce. J. Amer. Soc. Hort. Sci. 114:638-642.

Klee, H.J. and D.G. Clark. 2002. Manipulation of ethylene synthesis and perception in plants: The ins and the outs. HortScience 37:6-8. 
Klee, H.J., M.B. Hayford, K.A. Kretzmer, G.F. Barry, and G.M. Kishore. 1991. Control of ethylene synthesis by expression of a bacterial enzyme in transgenic tomato plants. Plant Cell 3:1187-1193.

Lelievre, J.M., A. Latche, B. Jones, M. Bouzayen, and J.C. Pech. 1997. Ethylene and fruit ripening. Physiol. Plant. 101:727-739.

Mattoo, A.K. and W.B White. 1991. Regulation of ethylene biosynthesis, p. 21-42. In: A.K. Matto and J.C. Suttle (eds.). The plant hormone ethylene. CRC Press, Boca Raton, Fla.

McCollum, T.G. 2002. Molecular biology of host-pathogen interactions in harvested horticultural crops. HortScience 37:12-14.

McGlasson, W.B. 1985. Ethylene and fruit ripening. HortScience 20:51-53.

Morgan, P.W. and M.C. Drew. 1997. Ethylene and plant responses to stress. Physiol. Plant. 100:620-630.

Oeller, P.W., L. Min-Wong, L.P. Taylor, D.A. Pike, and A. Theologis. 1991. Reversible inhibition of tomato fruit senescence by antisense RNA. Science 254:437-439.

Pratt, H.K. and J.D. Goeschl. 1969. Phyiological roles of ethylene in plants. Annu. Rev. Plant Physiol. 20:541-584.

Primrose, S.B. 1976. Ethylene-forming bacteria from soil and water. J. Gen. Microbiol. 97:343-346.

Raskin I. 1991. Ethylene in vegetative growth, p. 183-192. In: A.K. Matto and J.C. Suttle (eds.). The plant hormone ethylene. CRC Press, Boca Raton, Fla.

Reid, M.S. 1985. Ethylene and abscission. HortScience 20:45-50.

Robbins, J.A., M.S. Reid, J.L. Paul, and T.L. Rost. 1985. The effect of ethylene on adventitious root formation in mung bean (Vigna radiata) cuttings. J. Plant Growth Regulat. 4:147-157.

Rugini, E., G. Bongi, and G. Fontanazza. 1982. Effects of ethephon on olive ripening. J. Amer. Soc. Hort. Sci. 107:835-838.

Saftner, R.A., J.A. Abbott, W.S. Conway, and C.L. Barden. 2003. Effects of 1- methylcyclopropene and heat treatments on ripening and postharvest decay in 'Golden Delicious' apples. J. Amer. Soc. Hort. Sci. 128:120-127.

Saltveit, M.E. 1999. Effect of ethylene on quality of fresh fruit and vegetables. Postharvest Biol. Technol. 15:279-292.

See, R.M. and C.L. Foy. 1983. Effect of ethephon and daminozide on the respiration of isolated leaf cells. J. Plant Growth Regulat. 2:9-17.

Sisler, E.C. and C. Wood. 1988. Interaction of ethylene and $\mathrm{CO}_{2}$. Physiol. Plant. 73:440-444.

Sisler, E.C., M.S. Reid, and S.F. Yang. 1986. Effect of antagonists of ethylene action on binding of ethylene in cut carnations. J. Plant Growth Regulat. 4:213-218.

Soundheimer, E. 1957. The isolation and identification of 3-methyl-6-methoxy-8-hydroxy-3,4-dihydroisocoumarin in carrots. J. Amer. Chem. Soc. 79:5036-5039.

Stewart, I. and T.A. Wheaton. 1972. Carotenoids in citrus: Their accumulation induced by ethylene. J. Agr. Food Chem 20:448-449.

Takeda, K. and H. Shibota. 1981. Changes in microfibril arrangement on the inner surface on the epidermal cell walls in the epicotyl of Vignia angularis Ohwi et Ohashi during cell growth. Planta 151:385-392.

Watada, A.E. 1986. Effects of ethylene on the quality of fruit and vegetables. Food Technol. 40:82-85.

Wills, R.H.H., T.H. Lee, D. Graham, W.B. McGlasson, and E.G. Hall. 1981 Postharvest: An introduction to the physiology and handling of fruit and vegetables. AVI Publ. Co., Westport, Conn.

Yang, S.F. 1985. Biosynthesis and action of ethylene. HortScience 20:41-45.

Yang, S.F. and N.E. Hoffman. 1984. Ethylene biosynthesis and its regulation in higher plants. Annu. Rev. Plant Physiol. 35:155-189.

Zarembinski, T.I. and A. Theologis. 1994. Ethylene biosynthesis and action: A case of conservation. Plant Mol. Biol. 26:1579-1597. 